\title{
THE STUDY OF METHODS OF PRELIMINARY COOLING OF FRUITS
}

\author{
Marina Serdyuk \\ Department of Technology of Processing and Storage of Agricultural Products \\ Tavria State Agrotechnological University \\ 18 B. Khmelnitsky ave., Melitopol, Zaporizhia region, Ukraine, 72312 \\ igorserduk@mail.ru \\ Dmitrij Stepanenko \\ Department of «Ecology and Zoology» \\ Melitopol State Pedagogical University named after Bohdan Khmelnytsky \\ 20 Lenin str., Melitopol, Zaporizhia region, Ukraine, 72313 \\ asija-2008@mail.ru \\ Svitlana Baiberova \\ Department of Technology of Processing and Storage of Agricultural Products \\ Tavria State Agrotechnological University \\ 18 B. Khmelnitsky ave., Melitopol, Zaporizhia region, Ukraine, 72312 \\ bajberovas@gmail.com \\ Nonna Gaprindashvili \\ Department of Technology of Processing and Storage of Agricultural Products \\ Tavria State Agrotechnological University \\ 18 B. Khmelnitsky ave., Melitopol, Zaporizhia region, Ukraine, 72312 \\ nonnagap@mail.ru \\ Alina Kulik \\ Department of Technology of Processing and Storage of Agricultural Products \\ Tavria State Agrotechnological University \\ 18 B. Khmelnitsky ave., Melitopol, Zaporizhia region, Ukraine, 72312 \\ alina_potapenko@ukr.net
}

\begin{abstract}
The studies were aimed at scientific grounding of expedience of combination of preliminary cooling of apples, pears and plums and their processing by antioxidant compositions before the long storage and also at establishing of the optimal regimes and methods of this technological operation. The objects of studies were apple, pear and plums fruits of the different pomological species. As a result of studies was offered the combined method that provides preliminary cooling of apple fruits firstly by hydro-cooling in solutions of antioxidant compositions during 1 hour to the temperature in fruit center $8,5^{\circ} \mathrm{C}$, then additional cooling in AOC solutions during 1,5 hours to the temperature in fruit center $9{ }^{\circ} \mathrm{C}$, additional cooling in chamber of intensive cooling during 50 minutes to the temperature in fruit center $1{ }^{\circ} \mathrm{C}$. For plum: hydro-cooling in AOC solutions during 40 minutes to the temperature in fruit center $9^{\circ} \mathrm{C}$, additional cooling in chamber of intensive cooling during 30 minutes to the temperature in fruit center $1{ }^{\circ} \mathrm{C}$. The use of such method of preliminary cooling provides the fast decrease of intensity of breath and thermal flux of fruits and essentially decreases the lost of their mass. It favors the prolongation of term of storage of fruit raw material with maximal preservation of quality and biological value. The received data and their scientific grounding give a possibility to recommend producers to use the offered method of preliminary cooling in production conditions.
\end{abstract}

Keywords: preliminary cooling, distinol, lecithin, ascorutinum, fruit thermal flux.

DOI: 10.21303/2504-5695.2016.00148 C Marina Serdyuk, Dmitrij Stepanenko, Svitlana Baiberova, Nonna Gaprindashvili, Alina Kulik

\section{Introduction}

The use of artificial cold is one of the main methods of keeping quality and biological value of fruit production. But the advantages of this storage method are not fully used. It concerns the first stage of using low temperatures - preliminary cooling $[1,2]$. 
Preliminary cooling is a technological process of fast temperature lowering from the initial one to the temperature of further storage of fruits [3].

After harvest the complete physiological-biochemical and physical processes take place in fruit raw material. The main ones are evaporation of humidity, breath and ripening [4].

The result of excessive humidity evaporation is the losses of fruit mass that are visually manifested in the loss of tissues turgor and withering [5].

Breath is considered as the main physiological process after harvest period that realizes three functions in organism. At first, the energy, released at substrates oxidation is transformed into converted forms of cellular energy and used at the support of living functions and further development of fruits. The second one it is provision of cells with metabolites that are created at substrates oxidation and used in diverse biosyntheses. As a result of balanced flowing of biochemical processes the ripening processes take place and fruits gain the best consumer properties. The third function is connected with thermogenesis that is energy dissipation as heat. As a result the fruits with high breath intensity evolve in chamber space the large amount of heat that needs the significantly more cooling productiveness of equipment [6].

The breath intensity of fruit raw material depends on type, specie, ripeness degree. But the most influential factor is temperature. Thus, at temperature $20^{\circ} \mathrm{C}$ fruits breath flows almost 5 times more actively that at $0{ }^{\circ} \mathrm{C}[7]$.

The timely preliminary cooling decreases intensity of breath and thermal flux of fruits, decelerates the tempos of accumulation and expenditures of energetic substrates for living processes of vegetative tissues that significantly detains the ripening process [8].

But only the use of artificial cold does not provide the stable decrease of breathe intensity during the whole period of fruits storage. In addition to artificial cold the regulated and modified gas medium, ozonization, ionization, processing by 1-methylcyclopropene are used [9].

In Tavria state agrotechnological university (Melitopol, Ukraine) since 1994 are carried out the researches on the use of antioxidant compositions for processing of fruits before storage. The use of this technology gives a possibility to stabilize the breath intensity at the low level during the whole period of fruits storage, to decrease their thermal flux and mass losses.

The processing by antioxidant compositions can be realized by the different methods: the spraying in garden or on the line of fruits preparation to storage, irrigation or immersion [10]. At the further scientific studies authors faced the question as to possibility to combine technological operations of fruits processing with antioxidant compositions and preliminary cooling. The research is dedicated to the solution of this question.

Taking it into account, the authors' researches were aimed at scientific grounding of expedience of combination of preliminary cooling of fruits and their processing with antioxidant compositions before the long storage and also establishing of the optimal regimes and methods of this technological operation.

\section{Materials and methods of research}

The researches were carried out in Tavria state agrotechnological university (Melitopol, Ukraine). The objects of research were apple fruits of species Aidared. Golden, Delicious, Renet Simirenko, Florina, Starcrimson, pear fruits of species Crimea Raison and Conference, plum fruits Voloshka and Stanley, entered to the State list of species of plants, suitable for spreading in Ukraine.

Preliminary cooling was carried out by the following methods:

Variant 1. Apples and pears of the first, plums of the higher commodity sort, packaged in boxes, were sent for preliminary cooling. At that fruits were processed with cold air in experimental chambers of the slow cooling with temperature $2 \ldots 5^{\circ} \mathrm{C}$, speed of the air movement $0,5 \mathrm{~m} / \mathrm{s}$, air exchange ratio 30 volumes for hour. Relative humidity of the air in chambers $90 \ldots 95 \%$.

Variant 2. Apples and pears of the first, plums of the higher commodity sort, packaged in boxes, were sent for preliminary cooling. Fruits were processed with cold air in chambers of intensive cooling. The process was carried out in following regime parameters: temperature $-2 \ldots-4{ }^{\circ} \mathrm{C}$, speed of the air movement $3 \mathrm{~m} / \mathrm{s}$, air exchange ratio 90 volumes for hour. Relative humidity of the air in chambers was kept within $90 \ldots 95 \%$. 
Variant 3. Hydro-cooling: apples and pears of the first, plums of the higher commodity sort were cooled in bathes, filled with cooling medium. The solutions of antioxidant compositions (SAO) were used as cooling medium. Among them composition including ionol, dimethyl sulfoxide and lecithin (DL), composition including ascorbic acid, rutin, lecithin (AARL) and also composition including ionol, dimethyl sulfoxide and polyethylene glycol mixture (DPM).

The frequency of variant is fivefold.

The breath intensity of fruits was determined by the method of I. P. Tolmachev, by the mass losses before and after cooling - method of fixed trials [11]. At analysis and processing of experimental data were used the methods of variation statistics [12], with the help of computer programs «MS Office Excel 2007», «Statistica 6» package.

\section{Results of research}

In experimental chambers of the slow cooling the temperature decrease of consignment of apple fruits with mean diameter $65 \mathrm{~mm}$ was 8 hours, of consignment of pear fruits with mean diameter $70 \mathrm{~mm}-11$ hours, plum fruits with mean diameter $38 \mathrm{~mm}-5$ hours.

The general term of temperature decrease by intensive method of apple and pear fruits to the $0{ }^{\circ} \mathrm{C}$ was 2 hours, and plum $-1,33$ hours.

At the study of regimes of fruits preliminary cooling by the method of hydro-cooling the AOC solutions were used as cooling medium. For establishing of the optimal temperatures of working AOC solutions during fruits cooling their cryoscopic temperatures were determined. Thus, the ice-creating process of DPM composition takes place in temperature diapason from 0,7 to $-0,9^{\circ} \mathrm{C}$, Dl composition - from 0,6 to $0,1^{\circ} \mathrm{C}$ and AARL - at $0,3{ }^{\circ} \mathrm{C}$. The duration of crystallization of all working solutions of antioxidant compositions is 2 hours. So, for preliminary cooling of fruits can be recommended the temperature of working solutions $1,5 \pm 0,5^{\circ} \mathrm{C}$. The general duration of cooling apple and pear fruits to the $0{ }^{\circ} \mathrm{C}$ is near 3,5 hours, plum fruits $-1,5$ hours.

So, the most intensive method of preliminary cooling is cooling by air at the temperature $-2 \ldots-4{ }^{\circ} \mathrm{C}$ and at the speed of air movement $3 \mathrm{~m} / \mathrm{s}$.

The intensity of fruits breath before and after preliminary cooling and also thermal flux intensity at breath are given in the Table 1.

Table 1

Intensity of breath and thermal flux at cooling

\begin{tabular}{|c|c|c|c|c|c|}
\hline \multirow{2}{*}{ Fruit specie } & \multirow{2}{*}{ Cooling method } & \multicolumn{2}{|c|}{ Breath intensity, $\mathrm{mg} \mathrm{CO}_{2} / \mathrm{kg} \cdot$ hour } & \multicolumn{2}{|c|}{ Thermal flux intensity, $\mathrm{kJ} / \mathrm{kg} \cdot{ }^{\circ} \mathrm{C}$} \\
\hline & & $1 *$ & $2 * *$ & 1 & 2 \\
\hline \multirow{6}{*}{$\begin{array}{c}\text { Apple fruits } \\
\text { (mean 2005-2006) }\end{array}$} & slow & & $11,314 \pm 0,580$ & \multirow{6}{*}{209,763} & 120,949 \\
\hline & intensive & & $4,792 \pm 0,406$ & & 51,227 \\
\hline & DL & $19622+0893$ & $5,815 \pm 0,438$ & & 62,157 \\
\hline & AARL & $19,0<2 \pm 0,893$ & $5,805 \pm 0,327$ & & 62,059 \\
\hline & DPM & & $5,712 \pm 0,445$ & & 61,059 \\
\hline & Combined & \multirow{8}{*}{$25,227 \pm 1,249$} & $4,881 \pm 0,456$ & & 52,178 \\
\hline \multirow{6}{*}{$\begin{array}{c}\text { Pear fruits } \\
\text { (mean 2002-2003) }\end{array}$} & slow & & $14,484 \pm 0,852$ & \multirow{6}{*}{269,679} & 154,837 \\
\hline & intensive & & $7,529 \pm 0,535$ & & 80,490 \\
\hline & DL & & $8,602 \pm 0,195$ & & 91,957 \\
\hline & AARL & & $8,102 \pm 0,272$ & & 86,607 \\
\hline & DPM & & $8,442 \pm 0,316$ & & 90,247 \\
\hline & Combined & & $7,415 \pm 0,484$ & & 79,261 \\
\hline \multirow{6}{*}{$\begin{array}{c}\text { Plum fruits } \\
\text { (mean 2010-2011) }\end{array}$} & slow & & $7,219 \pm 0,424$ & \multirow{6}{*}{297,023} & 77,180 \\
\hline & intensive & & $4,385 \pm 0,522$ & & 46,879 \\
\hline & DL & & $4,582 \pm 0,176$ & & 48,977 \\
\hline & AARL & $27,785 \pm 0,706$ & $4,782 \pm 0,128$ & & 51,114 \\
\hline & DPM & & $5,057 \pm 0,249$ & & 54,057 \\
\hline & Combined & & $4,389 \pm 0,376$ & & 46,917 \\
\hline
\end{tabular}

Note: $1^{*}$ - before cooling, $2^{* *}$ - after cooling 
At that the thermal flux intensity of fruits was calculated by the following formula:

$$
\mathrm{Q}=\mathrm{q}_{\mathrm{sp}} \mathrm{I},
$$

where $\mathrm{q}_{\mathrm{sp}}$ - specific breath warmth, $10,69 \mathrm{~kJ}$ for $1 \mathrm{~g}$ of $\mathrm{CO}_{2}$; I - fruits breath intensity, $\mathrm{mg}$ of $\mathrm{CO}_{2} / \mathrm{kg}$ for year.

Specific breath warmth was determined by the following way, the process of aerobic breath can be described by equation:

$$
\mathrm{C}_{6} \mathrm{H}_{12} \mathrm{O}_{6}+6 \mathrm{O}_{2} \rightarrow 6 \mathrm{H}_{2} \mathrm{O}+6 \mathrm{CO}_{2}+2824, \mathrm{~kJ} \text {. }
$$

Since molecular mass of $\mathrm{CO}_{2}$ is 44 , according to equation of breath process is evolved $44 \cdot 6=264 \mathrm{~g}$ of $\mathrm{CO}_{2}$. So, for $264 \mathrm{~g}$ of $\mathrm{CO}_{2}$ will be evolved $2824 \mathrm{~kJ}$ of heat and at evolution of $1 \mathrm{~g}$ of $\mathrm{CO}_{2}$ will be evolved $10,69 \mathrm{~kJ}$ of heat.

The received data state the dependence of intensity of fruits breath at harvest from their specific features. The most breath intensity was inherent to plum fruits, the less - to pear fruits and the minimal one - to apple fruits. The mean coefficient of changeability of this parameter was $24 \%$, with variation depending on specie and sort of fruits within $13 \%$ (plum fruits of Italian Ugorka sort) up to $39 \%$ (pear fruits of Cure sort).

According to that the thermal flux intensity of plum fruits at harvest was maximal almost $300 \mathrm{~kJ} / \mathrm{kg} \cdot{ }^{\circ} \mathrm{C}$, pear fruits $-270 \mathrm{~kJ} / \mathrm{kg} \cdot{ }^{\circ} \mathrm{C}$, apple fruits $-210 \mathrm{~kJ} / \mathrm{kg} \cdot{ }^{\circ} \mathrm{C}$.

Along with it the speed constant of decrease of plum fruits breath was 2,3 and 2,8 times higher than in apple and pear fruits respectively (Table 2). It means that at cooling of plum fruits the additional thermal load from their breath decreases significantly faster.

Table 2

Speed constants of decrease of breath intensity of fruits at cooling

\begin{tabular}{cccccc}
\hline \multirow{2}{*}{ Fruit species } & \multicolumn{5}{c}{ Speed constants at methods of preliminary cooling, $\mathbf{k ~ m i n}^{-1}$} \\
& slow & intense & Dl & AARL & DPM \\
\hline Apple fruits & $-0,0043$ & $-0,0229$ & $-0,0131$ & $-0,0134$ & $-0,0132$ \\
Pear fruits & $-0,0036$ & $-0,0238$ & $-0,0129$ & $-0,0154$ & $-0,0150$ \\
Plum fruits & $-0,0101$ & $-0,0438$ & $-0,0361$ & $-0,0387$ & $-0,0355$
\end{tabular}

Maximal value of speed constant was at intense cooling of all fruit types, with exceeding of speed constant of slow cooling in 6,6 times for pear fruits, 5,3 times - for apple fruits and in 4,3 times - for plum fruits. At hydro-cooling in AOC solutions the speed of breath intensity decrease was lower comparing with intensive one in 1,6, 1,5 and 1,2 times respectively.

So, preliminary cooling by intensive method favors maximally fast decrease of breath intensity and thermal flux of fruits.

Along with it the losses of fruit mass at intensive cooling were maximal and varied from $0,56 \%$ in pear fruits to $0,44 \%$ in plump fruits. At decrease of the temperature in experimental chambers of the slow cooling the mass losses were less for apples in 1,97 times and pear and plum fruits - in 3 times.

Thus, the high speed of air movement intensifies the process of cooling fruits. The result is more fast and effective braking of breathing process. But at that the natural losses of fruit mass increase.

At fruits cooling in AOC solutions the losses of fruit mass were absent at all and the speed and degree of braking of breathing processes was not essentially less than at intensive method.

Taking it into account, there was considered the combined method that provided preliminary fruits cooling firstly in working AOC solutions, then additional cooling in chambers of intensive cooling. At additional cooling the drying process also takes place. At that from the fruits surface is excreted the excessive humidity that remains after previous stage of technological processing instead of the natural one. 
Duration of 1 and 2 stages of combined preliminary cooling was determined based on the speed of intensive and hydro-cooling processes. The speed of processes of temperature decrease was determined by the formula (2):

$$
\vartheta=\tan \alpha=\frac{\Delta \mathrm{t}}{\Delta \tau}
$$

where $\vartheta$-the speed of cooling process, ${ }^{\circ} \mathrm{C} / \mathrm{min}, \tan \alpha$ - tangent of tilt angle of straight line or the first derivative of equation $\mathrm{t}=\mathrm{a} \tau+\mathrm{b}, \Delta \mathrm{t}$ - difference between initial and final temperatures, ${ }^{\circ} \mathrm{C}$, $\Delta \tau$ - time difference, min.

The speed of intensive cooling of apples was $0,15^{\circ} \mathrm{C} / \mathrm{min}$, pear fruits $-0,16{ }^{\circ} \mathrm{C} / \mathrm{min}$, plum $-0,26{ }^{\circ} \mathrm{C} / \mathrm{min}$. The speed of hydro-cooling was equal $0,099,0,106$ and $0,220^{\circ} \mathrm{C} / \mathrm{min}$, respectively.

According to that, the following regimes of stages of combined cooling were established:

For apple fruitsi: 1 stage - hydro-cooling in AOC solutions during 1 hour to the temperature in fruit center $8,5^{\circ} \mathrm{C}, 2$ stage - additional cooling in the chamber of intensive cooling during 50 minutes to the temperature in fruit center $1^{\circ} \mathrm{C}$;

For pear fruitsi: 1 stage - hydro-cooling in AOC solutions during 1,5 hour to the temperature in fruit center $9^{\circ} \mathrm{C}, 2$ stage - additional cooling in the chamber of intensive cooling during 50 minutes to the temperature in fruit center $1^{\circ} \mathrm{C}$;

For plum fruits: 1 stage - hydro-cooling in AOC solutions during 40 minutes to the temperature in fruit center $9^{\circ} \mathrm{C}, 2$ stage - additional cooling in the chamber of intensive cooling during 30 minutes to the temperature in fruit center $1^{\circ} \mathrm{C}$.

The losses of fruit mass at combined cooling method varied from $0,005 \%$ for plum fruits to $0,014 \%$ - for apple and pear fruits. The constant of speed of decrease of breath intensity for apple fruits was $0,0245 \mathrm{~min}^{-1}$, for pear fruits $-0,0215 \mathrm{~min}^{-1}$ and for plum fruits $-0,045 \mathrm{~min}^{-1}$, that is did not essentially differ from the constant at intensive cooling.

Thus, combined method of preliminary cooling is the most acceptable by both regime parameters and technological indices of fruits quality.

\section{Conclusions}

It was established, that combined method that provides firstly preliminary cooling in the working solutions of antioxidant compositions and the further cooling by intensive method was characterized with the high constant of the speed of decrease of breath intensity and thermal flux of fruits and the low level of natural mass losses. At that the quantitative value of mass losses varied from $0,005 \%$ for the plum fruits to $0,014 \%$ - for pears and apples.

The received data and their scientific grounding give a possibility to recommend producers to carry out simultaneously the preliminary cooling and processing of fruits with antioxidant compositions before their further storage. At that it is necessary to carry out the following technological operations gradually: harvest of fruits, inspection, sorting, calibration, packaging in boxes, transportation to the place of storage, processing with antioxidant compositions and preliminary cooling by combined method: 1 stage - temperature of solutions $1,5 \pm 0,5^{\circ} \mathrm{C}$, duration $40 \mathrm{~min} \ldots 1,5$ hour, 2 stage: temperature of cooling air $-2 \ldots-5^{\circ} \mathrm{C}$, relative humidity of the air $95 \%$, movement speed $3 \mathrm{~m} / \mathrm{s}$, duration $30 \ldots 50 \mathrm{~min}$.

Unfortunately the modern lines of fruits preparation to storage are absent in Ukraine. So, the further studies will be devoted to the selection of technological equipment for the line of fruits preparation to storage using antioxidant compositions.

\section{References}

[1] Choi, J.-H., Yim, S.-H., Cho, K.-S., Kim, M.-S., Park, Y.-S., Jung, S.-K., \& Choi, H.-S. (2015). Fruit quality and core breakdown of "Wonhwang" pears in relation to harvest date and pre-storage cooling. Scientia Horticulturae, 188, 1-5. doi:10.1016/j.scienta.2015.03.011

[2] Wang, Y., Xie, X., \& Long, L. E. (2014). The effect of postharvest calcium application in hydro-cooling water on tissue calcium content, biochemical changes, and quality attributes of sweet cherry fruit. Food Chemistry, 160, 22-30. doi:10.1016/j.foodchem.2014.03.073 
[3] Pathare, P. B., Opara, U. L., Vigneault, C., Delele, M. A., \& Al-Said, F. A.-J. (2012). Design of Packaging Vents for Cooling Fresh Horticultural Produce. Food and Bioprocess Technology, 5(6), 2031-2045. doi:10.1007/s11947-012-0883-9

[4] Both, V., Thewes, F. R., Brackmann, A., Ferreira, D. de F., Pavanello, E. P., \& Wagner, R. (2016). Effect of low oxygen conditioning and ultralow oxygen storage on the volatile profile, ethylene production and respiration rate of "Royal Gala" apples. Scientia Horticulturae, 209, 156-164. doi:10.1016/ j.scienta.2016.06.028

[5] Guerra, M., \& Casquero, P. A. (2008). Effect of harvest date on cold storage and postharvest quality of plum cv. Green Gage. Postharvest Biology and Technology, 47(3), 325-332. doi:10.1016/j.postharvbio.2007.07.009

[6] Mo, Y., Gong, D., Liang, G., Han, R., Xie, J., \& Li, W. (2008). Enhanced preservation effects of sugar apple fruits by salicylic acid treatment during post-harvest storage. Journal of the Science of Food and Agriculture, 88(15), 2693-2699. doi:10.1002/jsfa.3395

[7] Fonseca, S. C., Oliveira, F. A. ., \& Brecht, J. K. (2002). Modelling respiration rate of fresh fruits and vegetables for modified atmosphere packages: a review. Journal of Food Engineering, 52(2), 99-119. doi:10.1016/s0260-8774(01)00106-6

[8] Wijewardane, R. M. N. A., \& Guleria, S. P. S. (2011). Effect of pre-cooling, fruit coating and packaging on postharvest quality of apple. Journal of Food Science and Technology, 50(2), 325-331. doi:10.1007/s13197-011-0322-3

[9] Li, G., Jia, H., Li, J., Li, H., \& Teng, Y. (2016). Effects of 1-MCP on volatile production and transcription of ester biosynthesis related genes under cold storage in "Ruanerli" pear fruit (Pyrus ussuriensis Maxim). Postharvest Biology and Technology, 111, 168-174. doi:10.1016/j.postharvbio.2015.08.011

[10] Serdyuk, M., Kalitka, V., Baiberova, S. (2014). Influence of exogenous treatment with antioxidants on dynamics of phenolic compounds during storage of apples. Eastern-European Journal of Enterprise Technologies, 5, 11 (71), 17-22. DOI: 10.15587/1729-4061.2014.27584

[11] Najchenko, V. M., Zamors'ka, I. L. (2010). Tehnologija zberigannja i pererobki plodiv ta ovochiv. Uman'.: vidavec' «Sochins'kij», 328.

[12] Dospehov, B. A. (1985). Metodika polevogo opyta (s osnovami statisticheskoj obrabotki rezul'tatov issledovanij). Moscow: Agropromizdat, 351. 